\section{Islamic Banking and Finance Review}

\section{三IBFF}

\section{Performance of Islamic Mutual Funds: A Comparison with Conventional Mutual Funds}

Muhammad Mahmood Shah Khan Syeda Hameeda Batool Gillani Director, Institute of Islamic Banking, Research Assistant, Institute of University of Management and Technology, Lahore, Pakistan.

\section{Sana Mansoor}

Islamic Banking, UMT, Lahore Pakistan.

hameeda.gillani@umt.edu.pk

Assistant Manager Finance, ViSigma Apparel Group Lahore, Pakistan.

Research Paper Information:

\section{Jo cite this article}

Khan, M. M. S., Gillani, S. H. B., \& Mansoor, S. (2015).

Performance of Islamic mutual funds: A comparison with C conventional mutual funds. Islamic Banking and Finance Review, 2 (1), 29-39.

$\underline{\text { Crossref }}$

\begin{tabular}{|l|c|}
\hline \multicolumn{2}{|c|}{ Atcess this article online } \\
\hline \\
\hline
\end{tabular}

\section{Contact 2nformation}

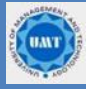

INSTITUTE OF ISLAMIC BANKING (IIB) UNIVERSITY OF MANAGEMENT AND TECHNOLOGY

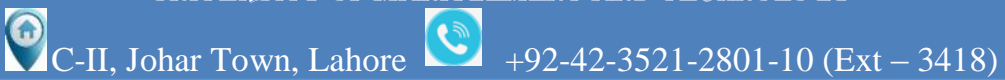

Volume 2

ISSN (E):

1436-H/ 2015

ISSN (P):

2413-2977

2221-5239

Journal do

https://doi.org/10.32350/ibfr

$$
\text { Issue doi) }
$$

https://doi.org/10.32350/ibfr.2015.02

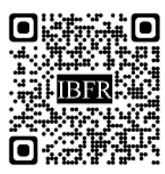

๘

This is an Open Access Journal

\section{Published By}

Institute of Islamic Banking University of Management and Technology (UMT)

\section{3}

$\underline{\text { https://iib.umt.edu.pk/ibfr/home.aspx }}$

@

ibfr@umt.edu.pk

This article is distributed under the terms of Creative Commons Attribution - Share Alike 4.0 International License.

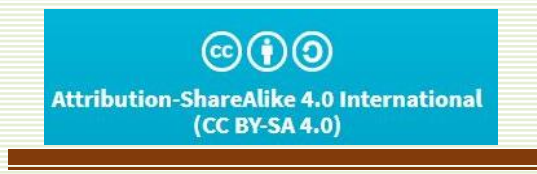

Indexing Partners

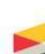

Crossre

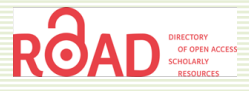

$R_{i}=$
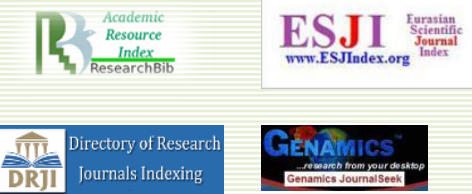

INDEX COPERNICUS

GENERALIMPACTFACTOR
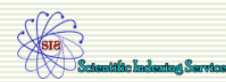


\title{
Performance of Islamic Mutual Funds: A Comparison with Conventional Mutual Funds
}

\author{
Muhammad Mahmood Shah Khan \\ Director, Institute of Islamic Banking \\ University of Management and Technology \\ Lahore, Pakistan. \\ Syeda Hameeda Batool Gillani \\ Research Assistant, Institute of Islamic Banking \\ University of Management and Technology \\ Lahore, Pakistan. \\ hameeda.gillani@umt.edu.pk
}

Sana Mansoor

Assistant Manager Finance, ViSigma Apparel Group

Lahore, Pakistan.

\begin{abstract}
Tslamic finance industry has been expanded in the last decade and has branched out itself from banking to other financial sectors like Islamic Assets Management and Islamic Insurance Companies. Islamic finance industry growth over the past decade is impressive comparative to conventional sector particularly at the time of financial crisis. The focus of this research study is to assess the performance of Islamic and Conventional mutual funds in Pakistan for the period of 7 years ranging from 2007 to 2013. The research also studied the impact of NAV on mutual funds and how the volatility influences the Islamic and Conventional mutual funds. This research is based on the sample of equity funds using all Asset Management Companies in Pakistan on the basis of availability of each fund's NAV. The findings suggest that mutual funds performance led to mixed trend. The results indicates that portfolio returns of Islamic funds are more clustered around mean that shows the level of consistency in the performance of the Islamic funds, whereas portfolio returns of the Conventional funds are more volatile and inconsistent comparatively. Concerning overall performance, Islamic funds performed better than Conventional funds.
\end{abstract}

Keywords: Mutual Funds, Net Asset Value, Volatility, Returns, Performance

Khan, Muhammad Mahmood. Shah., Gillani, Syeda Hameeda. Batool., \& Mansoor, Sana. (2015). Performance of Islamic Mutaul Funds: A Comparison with Islamic Mutual Funds. Islamic Banking and Finance Review, 2(1), 29-39. ISSN 2221-5239. (c) 2015 


\section{Introduction}

Islamic finance industry has diversified from banking sector to other financial sectors in the past three decades and now it includes institutions like Islamic mutual funds management companies, Islamic micro financing institutions and Islamic insurance (takaful) companies. The growth of Islamic finance sector over the past decade remains impressive, specifically during the time of financial crisis that hit the globally functional conventional financial markets quite badly. Islamic mutual fund industry enjoys attractive investment capital from Muslim as well as non-Muslim investors. Islamic mutual fund industry also faced radical change around the world and likewise in Pakistan.

In Pakistan, currently there are 15 Asset Management Companies that are managing Islamic as well conventional mutual funds. Islamic funds are almost $12 \%$ of the mutual funds industry in Pakistan (Economic Review, 2014). The introduction of Islamic mutual funds has widened the industry by attracting the investors who were previously resistant to invest in conventional funds because of religious concerns. The traditional investment mutual funds was introduced in Pakistan in 1962, while the first Islamic fund was introduced in 2002 that is almost 40 years later. Today, total assets in Islamic mutual funds managed within Pakistan are about Rs. 58 Billion (Economic Review, 2014). In Pakistan, all categories of funds available in the conventional and in the Islamic fund side, such as stocks, money market, sovereignty, fixed income, index tracking funds protection.

Mutual funds are such investments that pools money from different investors to purchase securities. Mutual fund is actually an investment vehicle created by the Assets Management Companies that specialized in pooling hoarded money from individual investors as well as institutional investors. However, these investors have their own preferences on the basis of their different risk threshold, liquidity needs and religious requirements. Individual investors give preference to make investment in mutual funds as their preferred investment vehicle to manage the risk and return profiles. Keeping in view the various complex needs of an Islamic country, realizing the fact that our financial market is based on the interest factor that does not conform to Islamic laws of Quran and Sunnah. However, it is difficult for the Muslim investors to freely invest in it. The increasing demand of alternative investment system 
which conforms to Islamic laws has promoted Pakistan government to introduce Islamic investment vehicle. This research study conducted to measure the performance of Islamic mutual funds and conventional mutual funds in Pakistan. The study evaluates comparatively which fund provide better return to capitalist, the Net Asset value (NAV) influence on the Islamic and conventional funds performance and the consequences of volatility on the Islamic and conventional mutual funds. This is a comparative study that aims to examine risk and return profile of mutual funds in Pakistan for the period across 07 years from 2007 to 2013.

\subsection{Significance of Study}

The traditional capital market has to follow the capital funding market laws, but Islamic funds, on the other hand, are subjected not only to the capital market laws but they have to follow economics of Islamic laws under the reflection of Shariah. On this basis of strategic differences, the study objective is to provide comprehensive understanding of the two different funds in the Pakistan capital market. Compared to conventional funds, Islamic funds are relatively new. Since the offering of Islamic mutual funds the researchers are interested to measure the comparative performance of risk-return profile of such funds.

\subsection{Research Question}

The study intends to observe the following research questions.

- Are there any performance differences between Islamic mutual funds and conventional mutual funds in Pakistan?

- Do Islamic mutual funds outperform Conventional mutual funds?

\section{$1.3 \quad$ Research Objectives}

- To explore whether Islamic funds provide better return to capitalist as compared to Conventional Funds.

- To measure how NAV influence on the Islamic and conventional funds performance.

- To evaluate the consequences of volatility on the Islamic and conventional mutual funds performance. 


\section{Literature Review}

The stock markets are mutually beneficiary for both lender and borrower and mediator of transfer financial resources from surplus to deficit respectively. The financial resources allocate efficiently since beneficiaries (public limited companies) invest in specialized productive projects which are not the potential of the funds provider (households). Stock markets are ultimate source to fulfill the liquidity requirement of the companies. The risk premium is depending on the covariation between assets return and market portfolio returns. The investor risk of variability in returns will compensate by diversified efficient portfolios (Khilji \& Nabi, 1993).

Brennan et al. (1993) observed that in the same size firms, stock prices of the mostly persuaded firms by investment analysts swiftly regulated than the least delimited firms. Even most analytical firms quickly respond to market returns as compared to the least consider firms (Brennan et al., 1993). According to Sharpe (1964) typical investor incurred two types of prices, interest rate and risk. The expected rate of return is directly related to risk in conventional concepts it also capitulate inference reliability, since investor bear low return on the asset which is least responded to the economics change and vice versa. To adjust capital assets price, he has to acquire diversified portfolio because each capital asset compute independently (Sharpe, 1964). Jones \& Wilson (1989) compared stocks with time to measure volatility. Increasing volatility is in fact a considerable matter to be discussed seriously. If suitable data were available for statistical inference then it will be good enough if "increased volatility" can be experimentally estimate for short term period of time (Jones \& Wilson, 1989).

Most of Pakistani investors make positive returns in equity markets like other markets. The return on stocks is not normally distributed, although hypothetical models are used very carefully (Husain and Uppal, 1998). The firms with surplus cash are more likely on high risk than the low excess cash and experienced low returns when markets are in slump. There is option of elevated investment in future but not surety of profitability. Resultant high cash firms like Islamic Banks are considerably risky (Simutin, 2010). Investors should hold small stocks to avoid variations in the price of assets and returns of the stocks. Diversified portfolio is best option for the investor of Small 
firms, which influenced largely by the external variations (Lamont el at., 2001). The macroeconomic variables like inflation, exchange rate, money supply and industrial index have pessimistic impact on stocks returns. An appropriate monetary policy can reduce inflation and increase the industrial production, exchange rate flow and money supply, ultimately impacting on price and expected returns (Sohail \& Hussain, 2009).

In competent capital market, investor's expectation regarding discount rate and cash flow manipulate the price of assets. Expected discount rate is negatively correlated to the dividend. The profitability and returns depend on each other and yield of firms dividends envisage with both. The variation in stocks prices are caused by the inverse correlation of profitability and the expected returns (Sadka, 2007). Rational investors of an economy make risk premium stock return above average if expected dividends assumed to be increased gradually than the risk free stocks with low interest rate. The noisy information stocks prices are explosive then the smooth dividends. The accurate information about firms controls the risk premium and cost of equity capital (Li, 2005).

Many Muslims reduce stock trading in the month of Ramadan due to the fact of immorality of peculation in view of Islamic rules. In Pakistan working hours reduced in month of Ramadan that is why stocks returns decline but average return does not effect at all in this holy month. This is significantly noted that least instability of the stock market observed in Ramadan and formed prosperity for investors to tackle stipulation judiciously (Husain, 1998).

\section{Research Methodology}

The aim of this study is to understand and promote the Islamic mutual fund industry in Pakistan. Moreover, it will ease the analysis of Islamic mutual funds in comparison with conventional mutual funds; how they work according to the principles of Islam, and how do they follow the performance of mutual funds. The research focus on equity based mutual funds and the sample consist of 05 Islamic and 05 Conventional mutual funds. Unit holder's distributed returns calculated for the period of 07 years, starting from January 2007 to December 2013. The data for the study has been taken from Mutual 
Funds Association of Pakistan $\left(\mathrm{MUFAP}^{1}\right.$ ) on random basis. The study focus on the application of quantitative technique to review the data, for this purpose confirmatory data analysis technique is used to review and gathered data to make inferences on testing predetermined hypothesis. The performance is compared by the following variables: Net Asset Value (NAV), Portfolio Returns $\left(\mathrm{R}_{\mathrm{p}}\right)$, Standard Deviation $(\sigma)$, Expected Returns $E\left(\mathrm{R}_{\mathrm{i}}\right)$, Volatility $(\mathrm{CoV})$. The returns on the mutual funds are derived using the rate of returns for each fund as calculated below:

$$
R_{p}=\frac{N A V_{t}-N A V_{t-1}}{N A V_{t-1}}
$$

Where, $\mathrm{Rp}=$ Total return of a portfolio; NAVt $=$ Net Asset Value at time $\mathrm{t}$; NAVt_1 = Net Asset Value one period before time $t$

NAV is market value per share on behalf of fund. This is investors' price to buy/sell fund shares from the fund company. It is obtained by dividing total of all cash and securities in the fund's portfolio, minus liabilities, divided by the number of shares outstanding. NAV calculation is based on the closing market price of a portfolio of securities. Using above performance measure; the performance of randomly selected both type of mutual funds shown in graphical presentation in Table 01 .

\section{Figure 01: Number and Amount of Mutual Funds}

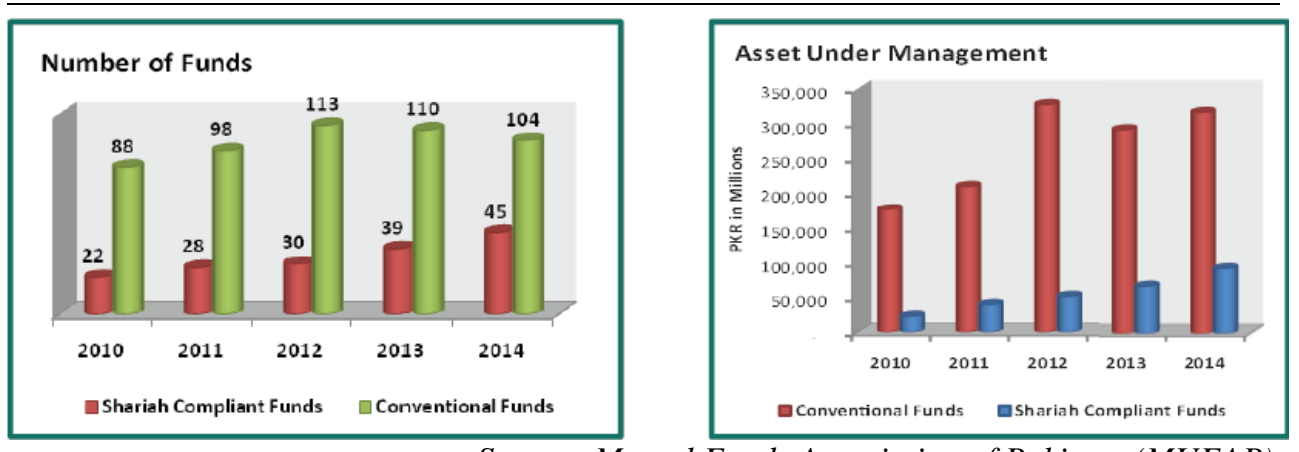

Source: Mutual Funds Association of Pakistan (MUFAP)

Portfolio returns (calculated using daily NAVs of the of each fund) of Islamic funds are more clustered around mean which show level of consistency in the

\footnotetext{
${ }^{1}$ MUFAP is a trade organization for Pakistan billions of rupees in the asset management industry. Its members manage money in a variety of investment vehicles, including stocks, bonds, money market instruments, government bonds and bank deposits. Its role is to ensure transparency in the mutual fund industry's high ethical behavior and growth.
} 
performance of the Islamic funds, whereas portfolio returns of the Conventional funds are more volatile and inconsistent comparatively. The total risk on investments is measured using standard deviation which is a measure of the conditions and the investment risks in important statistical variation; variation is a measure of investment risk. This applies not only to individual securities, mutual funds but risks as well. Distinct of the standard deviation, which is an absolute measure of variability, the coefficient of variation is a relative measure of volatility. The coefficient of variation $(\mathrm{CoV})$ is the ratio that the risk associated per unit of average returns, is expressed as follows:

Where

$$
\operatorname{CoV}=\frac{\sigma_{i}}{E\left(R_{i}\right)}
$$

$\sigma_{i} \quad=$ standard deviation (total risk) of asset $i$; and

$E\left(R_{i}\right)=$ average return of asset $i$.

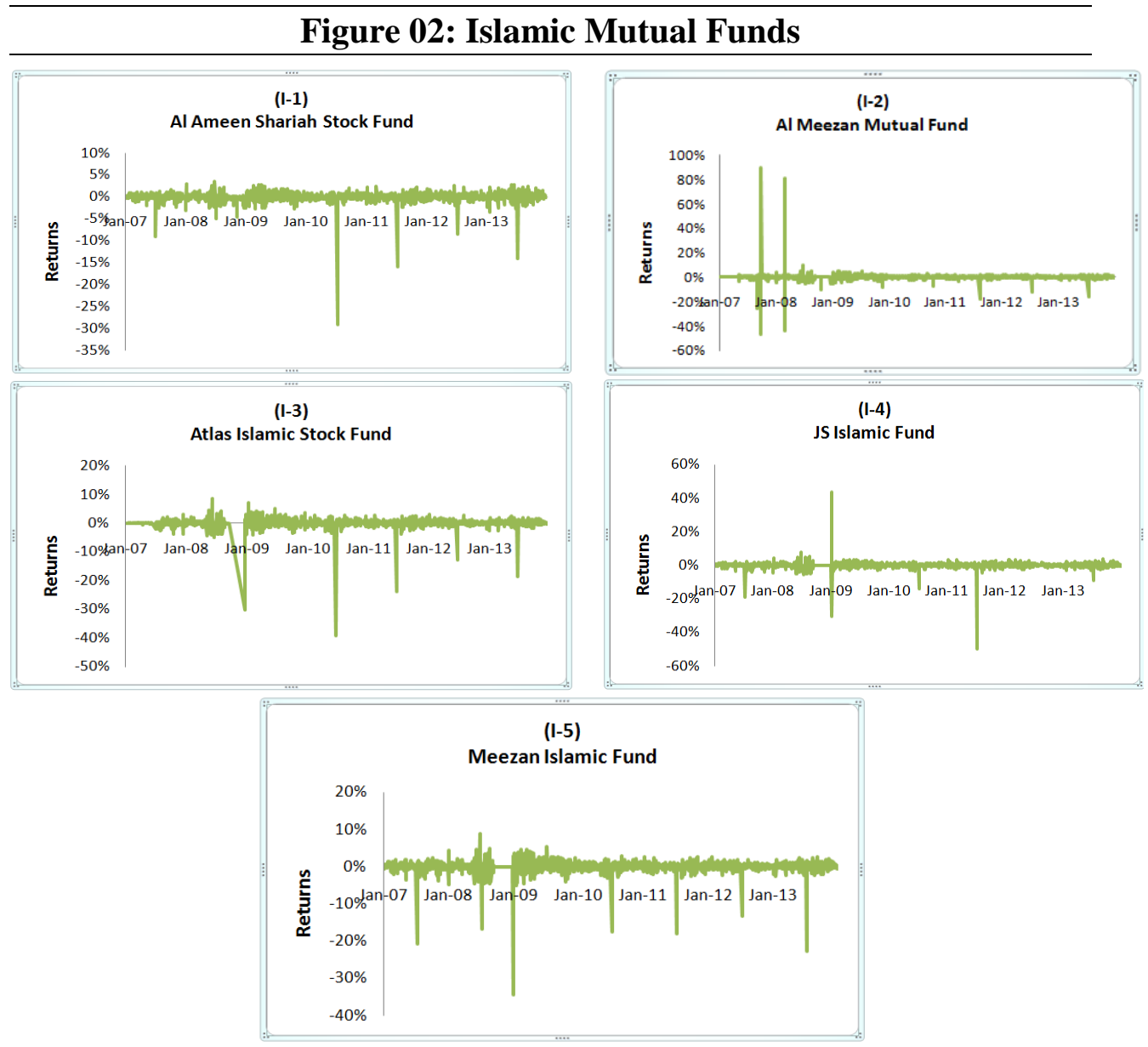




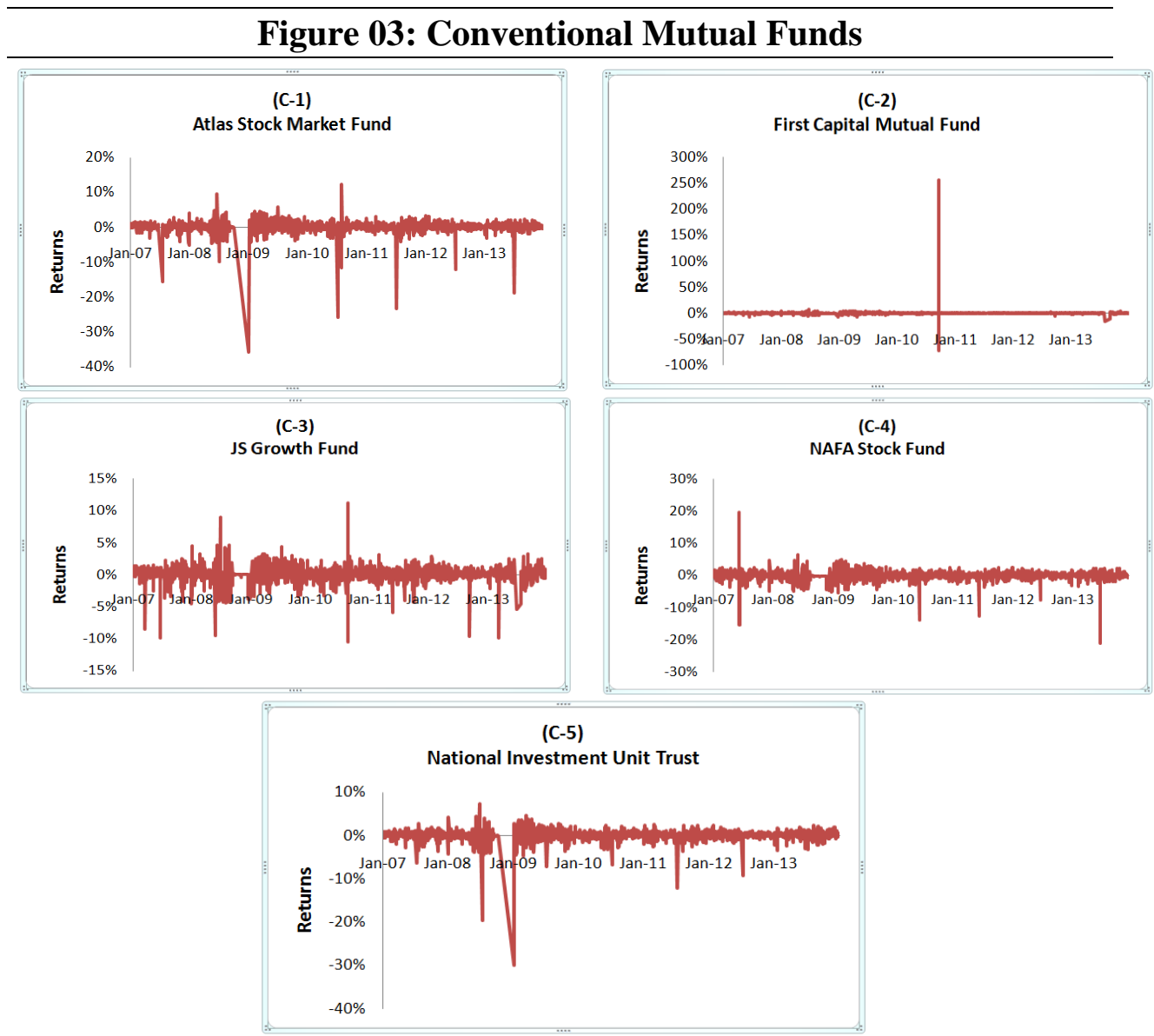

\section{Results \& Discussion}

Analyzing and interpreting the performance of 10 randomly selected equity funds through Confirmatory data analysis technique using graphs and charts. It is clear that overall daily Mean Return E( $\left.\mathrm{R}_{j}\right)$ of Islamic funds shows better performance as compared to conventional funds over the years for which funds are invested. Interpreting Standard Deviation $\left(\sigma_{i}\right)$, measures the dispersion of the data from its means the more data is separated, higher the difference of the norm. Using this risk measure it examined that how much return on the basis of expected returns on the fund deviates from its historical performance. Over the period of 07 years, observations showed mix trend of quantified variability. Out of total 10 mutual funds, 02 Islamic and 03 conventional funds can be considered less risky. More of Islamic funds are volatile having high standard deviation. Critically, we observe more the return more the risk. 
So we can say Islamic funds are performing better as their overall portfolio returns are better yet facing more risk.

\section{Table 01: Mutual Funds Deviation, Return and Variation}

\begin{tabular}{c|ccc}
\hline Mutual Funds & $\begin{array}{c}\text { Standard Deviation } \\
\mathbf{S D}_{\mathbf{i}}\end{array}$ & $\begin{array}{c}\text { Expected Return E } \\
\left(\mathbf{R}_{\mathbf{i}}\right)\end{array}$ & $\begin{array}{c}\text { Coefficient of } \\
\text { Variation }(\mathbf{C o V})\end{array}$ \\
\hline $\mathbf{I - 1}$ & 0.012 & $0.0041 \%$ & 298 \\
$\mathbf{I - 2}$ & 0.013 & $0.0625 \%$ & 21 \\
$\mathbf{I - 3}$ & 0.018 & $0.0254 \%$ & 71 \\
$\mathbf{I - 4}$ & 0.023 & $-0.0029 \%$ & -782 \\
$\mathbf{I - 5}$ & 0.017 & $0.0349 \%$ & 50 \\
$\mathbf{C - 1}$ & 0.017 & $0.0388 \%$ & 44 \\
$\mathbf{C - 2}$ & 0.077 & $0.1866 \%$ & 42 \\
$\mathbf{C - 3}$ & 0.013 & $-0.0101 \%$ & -125 \\
$\mathbf{C - 4}$ & 0.015 & $-0.0091 \%$ & -158 \\
$\mathbf{C - 5}$ & 0.014 & $0.0323 \%$ & 43 \\
\hline
\end{tabular}

To know the dispersement of variables, volatility can be determined using variance coefficient equation $(\mathrm{CoV})$. This measure tells us the degree of variation from one fund to another. A high $\mathrm{CoV}$ value reflects inconsistency and the level of dispersion among the samples within the group. Data of mutual funds taken in the study depicts that Islamic funds are less volatile than Conventional funds, as Islamic funds are less dispersed comparatively. Presenting the results through bar charts shows the significance of risk that a fund is assuming in comparison to its return. We can say Islamic funds trends to be more volatile on positive side whereas more of the conventional funds are negatively volatile may be facing some economic crisis. Risk and variability factor also implies that higher the funds tend to move more the volatility they have than other funds. Islamic funds are more volatile but provide better returns to investors.

Figure 04: Mutual Funds Volatility

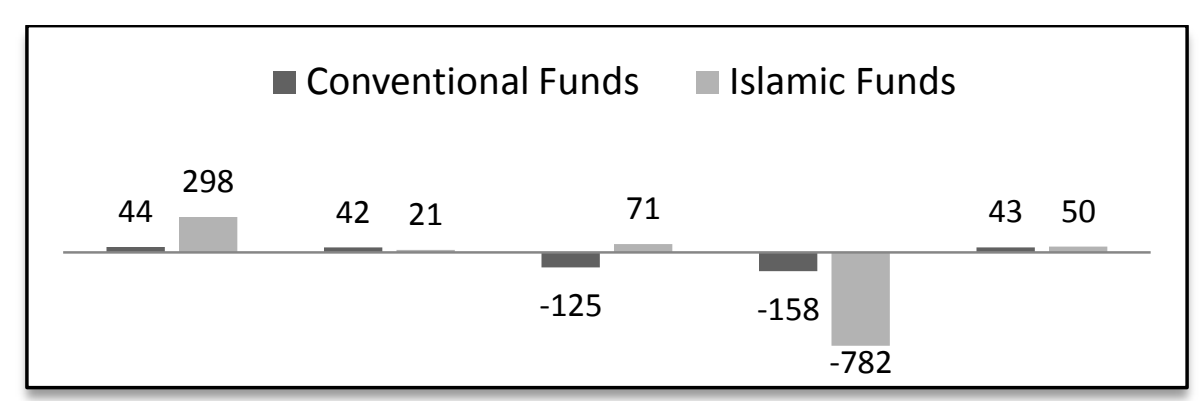




\section{Conclusion \& Recommendations}

Concerning returns, study strongly reject the null hypothesis in favor of research hypotheses as Islamic funds compared to Conventional funds give superior Returns to the investors. Overall expected returns (using daily portfolio returns) for each of 10 funds taken for the analysis of the Islamic fund is comparatively superior. The results regarding effect of daily NAV on fund's performance accept the alternate hypothesis because the behavior of daily price movement of the sample set has great influence on returns calculated using NAV which clearly depicts their influence on Islamic and Conventional mutual funds. The measure of variability clear indicates that the volatility affects the performance of both funds. Therefore null hypothesis can be rejected depending on results using equation of coefficient of variance, as results are not same across period ranging January 2007 to December 2013. The findings of the study may have important implications and recommendations for the investors and regulators of mutual fund industry. Research has evaluated mutual funds' performance which led to mixed trend. In view of the fact that Islamic funds had introduces 40 years later than conventional funds having limited market exposure make them a bit more volatile. Concerning overall performance Islamic funds performed better than Conventional funds; this provides good justification for the volunteer of Islamic investments vehicles. Whereas results also show some of the Islamic funds underperform, may be these funds are facing the problem of diversification of the portfolio. The need of hour is to mobilize the savings of investors through offering them investment opportunities as per Islamic laws. 


\section{References}

Brennan, M. J., Jegadeesh, N. \& Swaminathan, B. (winter, 1993). Investment Analysis and the

HUSAIN, F. and UPPAL, J. (1998). Distribution Of Stock Returns In An Emerging Market: The Pakistani Market. Pakistan Economic and Social Review, 36(1) pp. 47-72. Published by: Department of Economics, University of the Punjab.

Husain, F. (1998). Seasonality in the Pakistani equity market: The Ramadan effect. The Pakistan Development Review, 77-81

Jones, C. P., \& Wilson, J. W. (1989). Is Stock Price Volatility Increasing?. Financial Analysts Journal, 45(6), 20-26.

Khilji, N. M., \& Nabi, I. (1993). The Behaviour of Stock Returns in an Emerging Market: A Case Study of Pakistan [with Comments]. The Pakistan Development Review, 593-604.

Lamont, O., Polk, C., \& Saa-Requejo, J. (2001). Financial constraints and stock returns. Review of financial studies, 14(2), 529-554.

Li, G. (2005). Information quality, learning, and stock market returns. Journal of Financial and Quantitative Analysis, 40(03), 595-620.

Sharpe, W. F. 1964. Capital Asset Prices: A Theory of Market Equilibrium under Conditions of Risk. The Journal of Finance, 19(3) pp. 425-442. Published by: Wiley for the American Finance Association.

Sohail, N., \& Hussain, Z. (2009). Long-run and short-run relationship between macroeconomic variables and stock prices in Pakistan: The case of Lahore Stock Exchange. Pakistan Economic and Social Review, 183-198.

Simutin, M. (2010). Excess Cash and Stock Returns. Financial Management, 39(3) pp. 1197-1222. Published by: Wiley on behalf of the Financial Management Association International

Sadka, G. (2007). Understanding stock price volatility: The role of earnings. Journal of Accounting research, 45(1), 199-228. 